\title{
PENGGUNAAN BAKTERI PROBIOTIK SEBAGAI KONTROL BIOLOGI DALAM PRODUKSI MASSAL BENIH RAJUNGAN (Portunus pelagicus)
}

\author{
Bambang Susanto, Irwan Setyadi, Dewi Syahidah, Muhammad Marzuqi, dan Ibnu Rusdi")
} \begin{abstract}
ABSTRAK
Penelitian dilakukan untuk dapat mengontrol lingkungan secara biologis dalam produksi massal melalui penggunaan bakteri probiotik serta meningkatkan keragaan pertumbuhan larva rajungan (Portunus pelagicus). Penelitian menggunakan bak volume 4.000 liter dilengkapi dengan sistem aerasi dan suhu terkontrol, ditebar zoea-1 dengan kepadatan 50 ind./L, selama penelitian diberi pakan berupa rotifer, pakan komersial, dan nauplius artemia. Sebagai perlakuan adalah A) probiotik komersial, B) probiotik K-7, dan C) tanpa probiotik. Bakteri probiotik diinokulasikan ke dalam media pemeliharaan dengan kepadatan $10^{6} \mathrm{cfu} / \mathrm{mL}$. Hasil penelitian menunjukkan bahwa stadia megalopa dapat dicapai sekitar 7-8 hari dengan pemberian bakteri K-7 (B). Pemeliharaan larva rajungan pada perlakuan $A$ dan $C$ memerlukan waktu 9-10 hari. Sintasan megalopa pada perlakuan $A$, B, dan $C$ berturut-turut sebesar $8,37 \% ; 9,29 \%$; dan $7,90 \%$. Perlakuan $B$ menunjukkan gerakan megalopa lebih aktif. Populasi vibrio spp. pada perlakuan A) mencapai $9 \times 10^{2} \mathrm{cfu} / \mathrm{mL}$, B) $6 \times 10^{2} \mathrm{cfu} / \mathrm{mL}$, dan C) $1,0 \times 10^{3} \mathrm{cfu} / \mathrm{mL}$.
\end{abstract}

ABSTRACT: Utilization of bacteria as biological control on mass production of blue swimming crab fry (Portunus pelagicus). By: Bambang Susanto, I. Setyadi, D. Syahidah, M. Marzuqi, and I. Rusdi

The main constrain of aquaculture was insufficient of seed supply and high mortality caused by diseases infection. The aim of this trial was to evaluate the effectiveness of probiotics to control rearing water media and growth of blue swimming crab (Portunus pelagicus). Tank with the volume of 4,000 liter used with aeration system and controlled water temperature regulated by automatic water heater. Zoea-1 as test animal with stocking density of $50 \mathrm{ind} . / \mathrm{L}$ were reared, and fed with natural and artificial feed. The treatment were A (commercial probiotic), B (probiotic K-7), and $C$ (without probiotic). The result showed megalopa stage treated with probiotic $K-7$ (B) was achieved within 7-8 days and was achieved within faster than the $A$ and $C$ treatments which needed 9-10 days. Survival rate of megalopa stage on $A, B$, and $C$ were $8,37 \% ; 9,29 \%$; and $7,90 \%$ respectively. Population of vibrio sp. on such treatment were $A: 9 \times 10^{2} \mathrm{cfu} / \mathrm{mL}, \mathrm{B}: 6 \times 10^{2} \mathrm{cfu}$ $\mathrm{mL}$, and C: $1.0 \times 10^{3} \mathrm{cfu} / \mathrm{mL}$ respectively.

KEYWORDS: $\quad$ biological control, probiotic K-7, Portunus pelagicus, megalopa

\section{PENDAHULUAN}

Perbenihan rajungan (Portunus pelagicus) merupakan salah satu usaha yang sangat penting dalam penyediaan benih bagi budi daya yang berkesinambungan. Kendala yang dihadapi selama ini adalah masih rendahnya persentase sintasan yang dihasilkan dan belum ada teknologi perbenihan rajungan yang mudah diaplikasikan. Saat ini penelitian yang berkaitan dengan pembenihan rajungan belum banyak dilakukan, tetapi penelitian tentang kepiting bakau telah dilakukan oleh beberapa peneliti di antaranya Brick (1974), Kasry (1986), Yunus et al. (1996), dan Rusdi et al. (1999).

Uji coba pendahuluan menunjukkan bahwa pemeliharaan larva rajungan menghasilkan sintasan yang masih rendah dengan kondisi megalopa yang lemah. Persentase sintasan yang masih rendah ini diduga karena beberapa faktor, salah satu di antaranya adalah adanya serangan bakteri patogen. Pada usaha perbenihan umumnya masih menerapkan penggunaan bahan kimia atau antibiotik untuk menghindari kematian larva akibat serangan bakteri patogen (Vibrio sp.). Zafran et al. (1997) melaporkan bahwa vibriosis pada larva dapat diatasi antara lain dengan penggunaan bahan kimia dan antibiotik, namun dengan penggunaan antibiotik secara sembarangan dan tidak terkontrol selain tidak ekonomis akan berdampak mencemari lingkungan. Bahan tersebut dikhawatirkan dapat menimbulkan strain-strain bakteri yang resisten terhadap antibiotik. Dijelaskan pula bahwa penggunaan antibiotik akan mengakibatkan

\footnotetext{
-) Peneliti pada Balai Besar Riset Perikanan Budidaya Laut, Gondol
} 
terganggunya dinamika keseimbangan biologis dari mikroorganisme maupun kemampuan larva untuk beradaptasi dengan lingkungannya (Haryanti et al 1999; Maeda et al., 1992).

Beberapa pengamatan tentang serangan vibrio harveyi sebagai penyebab penyakit larva udang dan kepiting telah banyak dilakukan (Rosa et al., 1993; Rosa \& Zafran, 1998; Rosa \& Hatai, 1999). Upaya pengendalian organisme penyebab penyakit secara biologis dan pengontrolan kondisi lingkungan pemeliharaan dapat dilakukan dengan mempertahankan keseimbangan alami dari bakteri dan mikroorganisme lain dalam sistem pemeliharaan larva (Maeda, 1989; Gomes, 1992; Maeda \& Liao, 1994; Rosa \& Zafran, 1998). Hasil penelitian yang dilaporkan oleh Maeda et al. (1992), Maeda \& Liao (1994), Nogami \& Maeda (1992), menunjukkan bahwa dengan manipulasi bakteri, protozoa, dan mikroalga secara alami akan dapat menghasilkan proses pengelolaan lingkungan air yang sesuai untuk pemeliharaan larva rajungan (Portunus trituberculatus). Alternatif lain yang cukup efektif dan aman adalah pencegahan secara biologis dengan memanfaatkan bakteri sebagai probiotik yang berperan dalam memproduksi substansi penghambat pertumbuhan bakteri patogen. Balai Besar Riset Perikanan Budidaya Laut Gondol telah berhasil membuat isolat bakteri dengan kode $\mathrm{K}-7$ yang termasuk dalam kelompok Bacillus dan sudah diaplikasikan pada perbenihan udang dan kepiting bakau (Haryanti et al., 1997; Rusdi et al., 2002). Penelitian ini dilakukan dengan tujuan untuk dapat mengontrol lingkungan secara biologis dalam produksi massal melalui penggunaan bakteri probiotik dan meningkatkan keragaan pertumbuhan larva rajungan (Portunus pelagicus).

\section{BAHAN DAN METODE}

Penelitian ini dilakukan di Balai Besar Riset Perikanan Budidaya Laut (BBRPBL) Gondol-Bali. Hewan uji yang digunakan adalah rajungan (Portunus pelagicus), dan dilakukan dengan beberapa tahapan yaitu kultur bakteri Bacillus K-7 dan probiotik komersial, penyediaan induk, disain wadah untuk pemeliharaannya, penanganan, dan pemeliharaan larva.

\section{Kultur Bakteri Bacillus K-7 dan Probiotik Komersial}

Kultur bakteri Bacillus K-7, mengikuti metode yang digunakan untuk kultur bakteri Alteromonas sp. BY9, mengacu pada metode Nogami \& Maeda (1992) dan Haryanti et al. (2002). Bacillus K-7 diperoleh dari hasil isolasi di dalam alat pencernaan kepiting (Scylla spp.). Media kultur Bacillus K-7 terdiri atas beberapa campuran bahan yaitu bacto pepton : $5 \mathrm{~g}$, bacto soyton $3 \mathrm{~g}$, bacto yeast extract : $1 \mathrm{~g}$, air laut steril 1.000 $\mathrm{mL}$. Campuran bahan yang telah larut tersebut di optimasi dengan $\mathrm{pH} 6,8-7,0$ pada suhu $25^{\circ} \mathrm{C}$.

Untuk mendapatkan biakan bakteri dengan volume $5 \mathrm{~L}$ diperlukan inokulasi bakteri sebanyak $10 \mathrm{~mL}$ dan diinkubasi selama 48 jam pada suhu $25^{\circ} \mathrm{C}$. Selama inkubasi, diberi aerasi yang telah melalui filter 0,02 $\mathrm{mm}$ (Haryanti et al., 2002). Dari volume tersebut di atas, biakan bakteri K-7 dapat langsung digunakan dalam media pemeliharaan larva rajungan.

Probiotik komersial yang digunakan dalam penelitian ini adalah jenis probiotik yang dijual bebas di pasaran, diproduksi oleh perusahaan swasta di Bandung, setelah melalui analisis di Laboratorium PPU IH, ITB, Bandung. Kandungan bakteri yang terdapat dalam probiotik komersial tersebut adalah Bacillus spp., Lactobacillus spp., dan yeast. Probiotik ini dapat langsung digunakan dalam media pemeliharaan atau dengan mengaktifkan bakteri terlebih dahulu dengan beberapa tambahan media tertentu seperti gula merah dan dedak sesuai petunjuk dalam kemasan.

\section{Penyediaan Induk Rajungan}

Induk rajungan ditangkap dan dikoleksi oleh nelayan dari pantai Gilimanuk-Bali, yang telah diseleksi dengan ukuran panjang karapas $(\mathrm{CL})$ : 6,38 $\pm 0,54 \mathrm{~cm}$; lebar karapas (CW): 14,1 $\pm 1,05 \mathrm{~cm}$; dan bobot badan $(B W): 235 \pm 27,5 \mathrm{~g}$. Penetasan telur dilakukan dengan cara menginkubasi induk rajungan yang membawa telur ke dalam bak volume $250 \mathrm{~L}$ selama beberapa hari sesuai perkembangan embrio sampai siap untuk menetas. Setelah telur menetas menjadi larva (zoea-1), kemudian dilakukan pemisahan antara larva aktif dan tidak aktif melalui pengapungan, di mana larva yang melayang dan berkumpul ke permukaan air dinyatakan larva aktif. Larva didesinfektasi dengan larutan formaldehyde 25 $\mathrm{mg} / \mathrm{L}$ selama 30 menit, serta diberi larutan iodine 150 mg/L selama 10 menit. Pemberian formaldehyde dan iodine di atas dimaksudkan untuk menyucihamakan larva dari parasit dan bakteri.

\section{Disain Wadah untuk Pemeliharaan Larva}

Wadah yang digunakan dalam penelitian ini, dirancang sedemikian rupa sehingga air media dari bak pemeliharaan (I) dapat mengalir ke dalam bak resirkulasi (II) (Gambar 1). Kedua bak dihubungkan dengan pipa PVC, di mana bak pemeliharaan larva menggunakan sistem air lift, sedangkan dari bak resirkulasi dialirkan ke bak pemeliharaan larva dengan sistem gravitasi (Mann et al., 1999 dalam Rusdi et al., 1999). 


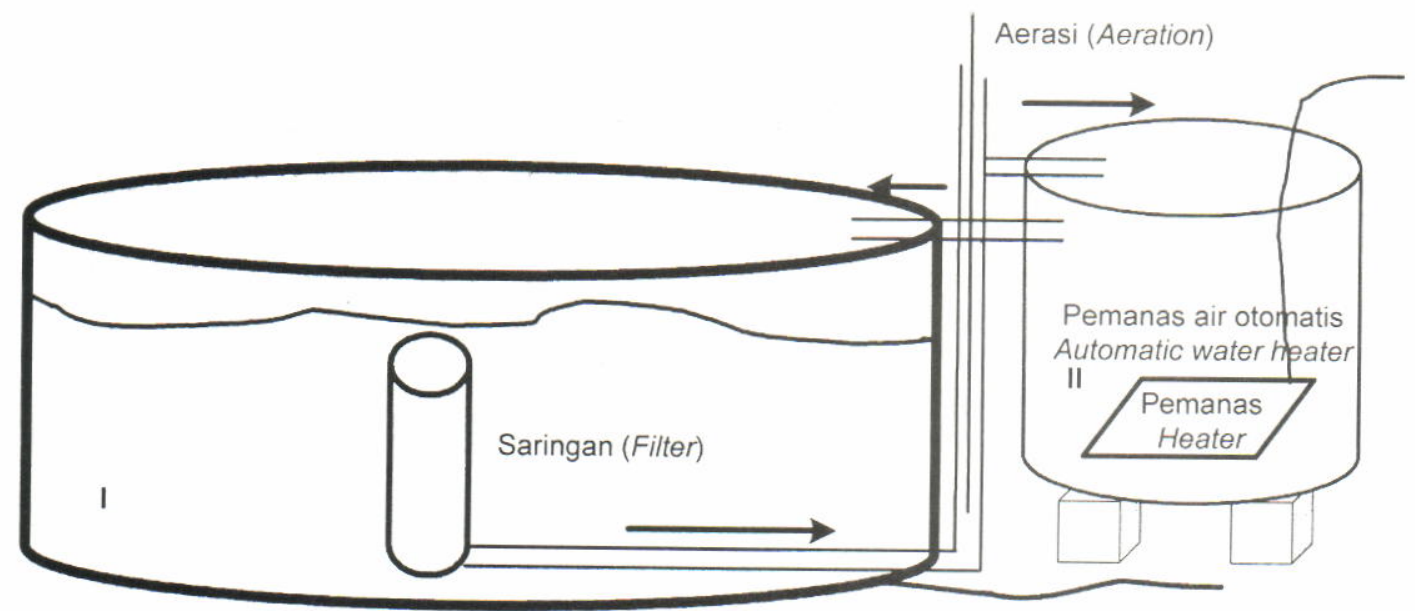

Gambar 1. Dua bak fiber glass, (I) untuk pemeliharaan larva dan (II) bak reserkulasi dengan pemanas otomatis (automatic water-heater) (Mann et al., 1999 dalam Rusdi et al., 1999). $\longrightarrow$ arah air mengalir

Figure 1. Two fiber glass containers, (I) larval rearing tank and (II) recirculation tank with automatic waterheater (Mann et al., 1999 In Rusdi et al., 1999). $\longrightarrow$ direction of flowing water

Bak pemeliharaan larva bervolume 4.000 liter dilengkapi dengan sistem aerasi, sedangkan bak resirkulasi volume 1.000 liter yang dilengkapi dengan alat pemanas otomatis (automatic water-heater) dan juga sistem aerasi. Bak untuk pemeliharaan larva berbentuk oval yang dindingnya dicat berwarna hitam dan bagian dasar bak dicat berwarna putih.

\section{Pemeliharaan Larva Rajungan}

Larva rajungan zoea-1 (Z-1) ditebar dengan kepadatan 50 ekor/liter, dan selama pemeliharaan diberi pakan berupa rotifer, naupli artemia, dan pakan komersial. Dosis pemberian rotifer dan naupli artemia sesuai hasil penelitian Nogami et al. (1995); Maeda et al. (1999), sedangkan pemberian pakan komersial dengan dosis meningkat seiring pertumbuhan stadia. Dosis pemberian pakan tersaji pada Tabel 1.

Perlakuan dalam penelitian ini adalah $\mathrm{A}$ ) pemberian bakteri probiotik komersial, B) bakteri probiotik K-7, dan C) tanpa penambahan bakteri. Pergantian air dilakukan setiap hari dengan cara membuang total volume air pada bak resirkulasi, kemudian mengisi kembali dengan air bersalinitas $30 \pm 1 \mathrm{ppt}$. Suhu media pemeliharaan diatur sekitar $30 \pm 1{ }^{\circ} \mathrm{C}$. Setiap pagi sekitar pukul 08.00 WITA, setelah pergantian air diinokulasikan bakteri probiotik dilakukan dengan kepadatan sekitar $10^{6} \mathrm{cfu} / \mathrm{mL}$. Parameter yang diamati adalah perkembangan larva dengan cara mengambil sampel masing-masing sebanyak 20 ekor pada setiap perkembangan stadia larva (Z-1 sampai megalopa) dan diamati di bawah mikroskop. Persentase sintasan megalopa rajungan dihitung dengan mengacu pada rumus Effendi (1979): yaitu S= Nt/NoX100\%, di mana S: Sintasan (\%), Nt: Jumlah akhir percobaan (ekor), No: jumlah awal percobaan (ekor). Total bakteri dalam air media pemeliharaan dilakukan dengan menggunakan media selektif TCBSA (Thiosulphate Citrate Bile Salt Sucrose Agar), sedangkan uji vitalitas larva dan megalopa didasarkan pada gerakan aktif dari hewan tersebut. Sebagai penunjang dimonitor juga kualitas air media pemeliharaan.

Tabel 1. Dosis pakan komersial, rotifer, dan naupli artemia yang diberikan selama pemeliharaan larva rajungan Table 1. Dosage of commercial feed, rotifer, and nauplius artemia given during larval rearing of blue swimming crab

\begin{tabular}{cccccc}
\hline $\begin{array}{c}\text { Stadia } \\
\text { Stage }\end{array}$ & $\begin{array}{c}\text { Dosis } \\
\text { Dosage } \\
\left(\mathbf{g} / \mathbf{m}^{\mathbf{3}} / \text { day) }\right.\end{array}$ & $\begin{array}{c}\text { Ukuran partikel } \\
\text { Particle size of } \\
\text { commercial feed }(\mathbf{m m})\end{array}$ & $\begin{array}{c}\text { Frek. pemberian } \\
\text { Feeding freq. } \\
\text { (time/day) }\end{array}$ & $\begin{array}{c}\text { Kepadatan rotifer Kepadatan artemia } \\
\text { Density of rotifer } \\
\text { (ind./mL) }\end{array}$ & $\begin{array}{c}\text { Density of nauplius } \\
\text { (ind./mL) }\end{array}$ \\
\hline Zoea-1 & $0.5--1.0$ & $5-30$ & 3 & 7 & 0.5 \\
Zoea-2 & $2.0--3.0$ & $30-90$ & 3 & 10 & 1 \\
Zoea-3 & $4.0--5.0$ & $30-90$ and 150-200 & 3 & 15 & 1.5 \\
Zoea-4 & $6.0--8.0$ & $150--200$ & 3 & 20 & 2 \\
Megalopa & 8 & $150--200$ & 3 & - & 2 \\
\hline
\end{tabular}




\section{HASIL DAN BAHASAN}

Penggunaan probiotik dalam media pemeliharaan larva rajungan dapat memacu pertumbuhannya. Hasil pengamatan pertumbuhan panjang karapas larva rajungan ( $P$. pelagicus) menunjukkan bahwa pemberian probiotik K-7 (perlakuan B) selalu lebih cepat dari perlakuan $\mathrm{A}$ dan $\mathrm{C}$ mulai hari ke-2 sampai hari ke-8. Sementara perlakuan probiotik komersial (A) juga memberikan pertumbuhan yang lebih cepat dibandingkan perlakuan tanpa probiotik (C).

Fuller (1987) dan Kamiso (2004) menyatakan bahwa probiotik merupakan mikrobia hidup di samping dapat meningkatkan kesehatan ikan dan lingkungan juga digunakan sebagai pakan suplemen, sehingga dapat memacu pertumbuhan dan mencegah terjadinya wabah penyakit. Dijelaskan pula bahwa probiotik apabila masuk kedalam tubuh ikan, udang, dan moluska akan berfungsi sebagai immunostimulan yang dapat meningkatkan ketahanan terhadap bakteri patogen. Pertumbuhan larva selama pengamatan tersaji pada Gambar 2.

Waktu yang diperlukan larva rajungan untuk bermetamorfosis menjadi megalopa sekitar 7-8 hari (perlakuan B), sedangkan pada perlakuan A dan $C$, sekitar 10 hari. Dilihat dari perkembangan stadia tersebut nampaknya penggunaan bakteri Bacillus K-7 (perlakuan B) dapat mempercepat perkembangan stadia zoea-megalopa dibandingkan perlakuan A dan C. Susanto et al. (2003) melaporkan bahwa pemeliharaan larva rajungan dengan pola pakan berbeda memerlukan waktu 8 atau 9 hari untuk mencapai stadia megalopa, sementara dengan pemberian frekuensi pakan berbeda dicapai dalam 10 dan 12 hari masa pemeliharaan.
Pemberian bakteri probiotik Bacillus K-7 diduga dapat meningkatkan daya cerna larva rajungan sehingga pertumbuhan larva menjadi lebih cepat. Haryanti et al. (2002) menyatakan bahwa dengan penambahan bakteri probiotik akan memberikan pertumbuhan yang lebih cepat, mutu benih lebih baik, serta dapat menekan populasi bakteri patogen. Hal tersebut juga dinyatakan oleh Garriques \& Arevalo (1995) dalam Haryanti et al. (1999) bahwa bakteri probiotik berperan sebagai 5 pengontrol biologis dalam akuakultur yaitu: 1) dapat melakukan kompetisi dengan bakteri patogen, 2) menambah nutrisi dengan nutrea esensial, 3) meningkatkan daya cerna dengan mengeluarkan enzim esensial, 4) langsung menyerap bahan organik terlarut, dan 5) memproduksi substansi yang dapat menghambat pertumbuhan bakteri oportunistik patogen. Dijelaskan pula bahwa saat perubahan stadia yang makin besar, larva mulai memangsa makanan semakin banyak. Dengan inokulasi bakteri probiotik dimungkinkan bakteri masuk ke dalam saluran pencernaan sebagai pakan suplemen (Fuller, 1987) dan terjadi stimulasi enzimatik dalam usus yang diketahui dapat membantu daya cerna larva (Haryanti et al., 1997).

Dari hasil pengamatan perkembangan larva pada perlakuan B menunjukkan bahwa pada hari ke-2 masa pemeliharaan terlihat sebanyak $25 \%$ zoea- 2 dan hari ke-4 larva rajungan sudah menjadi stadia Z-3 sekitar $60 \%$, sementara perlakuan A dan C pada pengamatan hari ke-4 masih sekitar $25 \%$ stadia Z-3. Nampaknya pemberian probiotik akan memacu perubahan stadia larva. Hal ini terlihat pada pengamatan hari ke-6 dari perlakuan B sebanyak $80 \%$ larva sudah mencapai stadia Z-4 dan pada hari ke-7 terdapat sebanyak $20 \%$ dari larva bermetamorfosis menjadi stadia megalopa, kemudian pada hari ke-8 semua larva (100\%) sudah mencapai

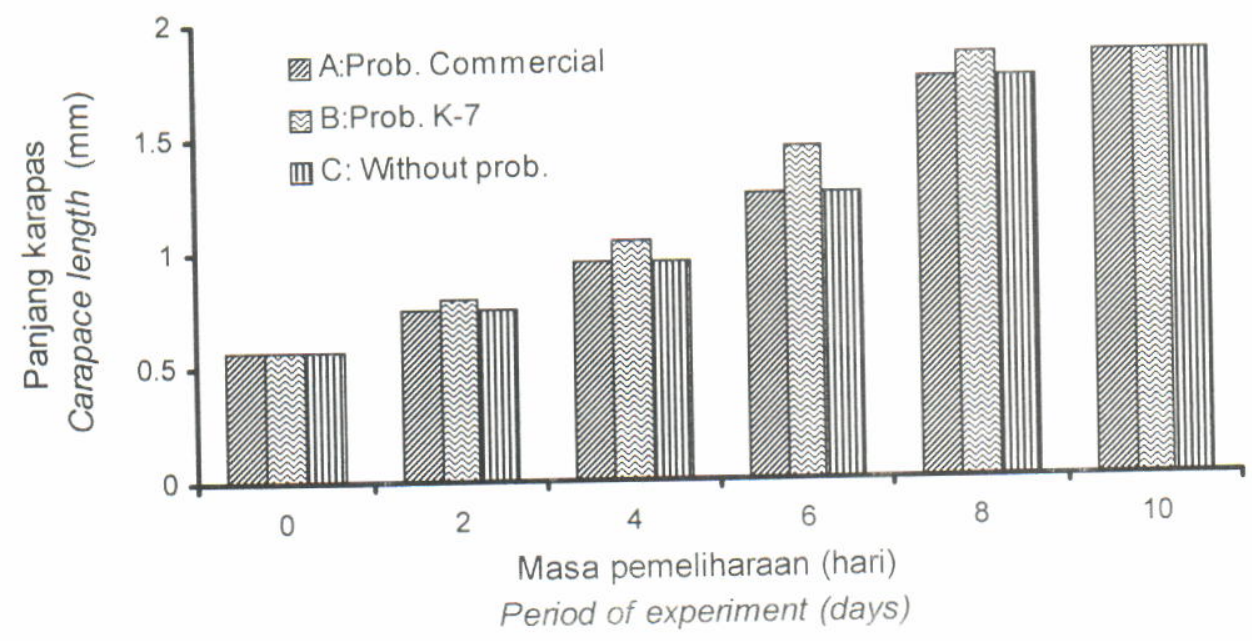

Gambar 2. Pertumbuhan panjang karapas $(\mathrm{CL})$ larva rajungan selama pengamatan Figure 2. Carapace lenghth (CL) of blue swimming crab larvae during experiment 
stadia megalopa. Sementara perlakuan A pada hari yang sama menunjukkan sekitar $80 \%$ megalopa dan perlakuan C hanya sekitar 20\% megalopa.

Larva rajungan setelah menjadi Z-3 dan Z-4 pada kondisi suhu air sekitar $29,5^{\circ} \mathrm{C}-31^{\circ} \mathrm{C}$ terlihat banyak melakukan gerak ke arah sumber aerasi dengan membengkokkan bagian abdomennya berkali-kali ke arah depan. Hal ini menunjukkan bahwa larva sehat dan gerakan tersebut dimanfaatkan pula untuk menangkap makanan. Heasman \& Fielder (1983) menyatakan bahwa frekuensi gerakan membengkokkan bagian abdomen dari larva kepiting (Scylla serrata) akan mengalami peningkatan seiring dengan peningkatan suhu, sehingga menunjang proses metabolisme lebih cepat. Perkembangan stadia larva dari Z-1 menjadi Megalopa tersaji pada Gambar 3.

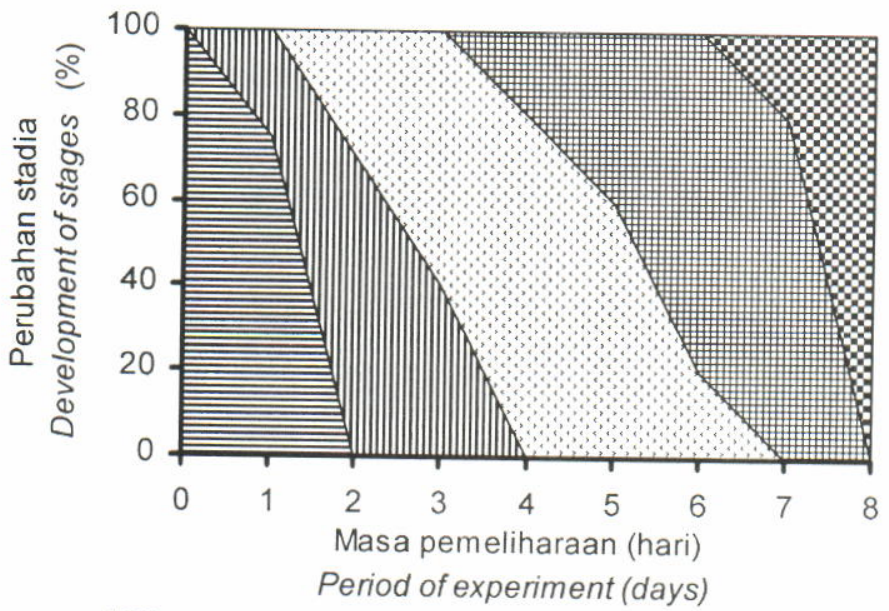

$8 \mathrm{M}$

囲Z-4

둔-3

미 Z-2

目Z-1

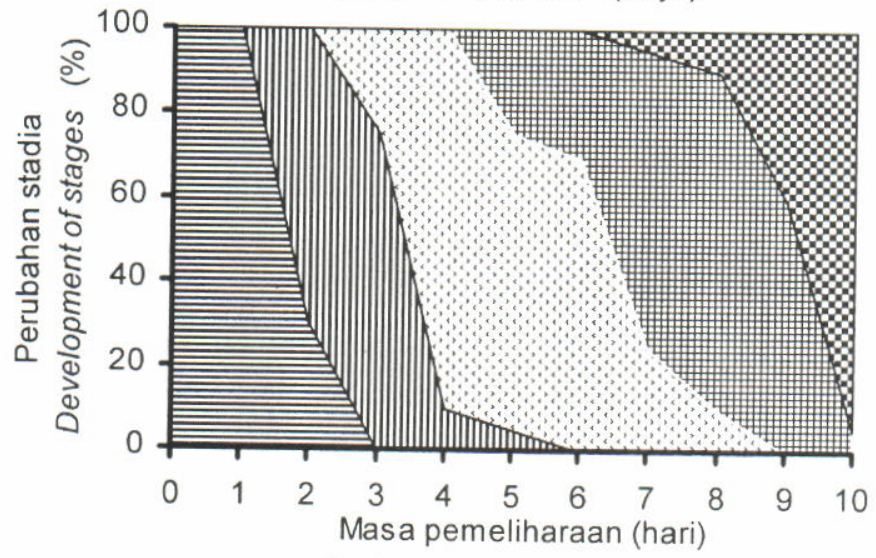

$8 \mathrm{M}$

II Z-4

○-3

血Z-2

目Z-1

Period of experiment (days)

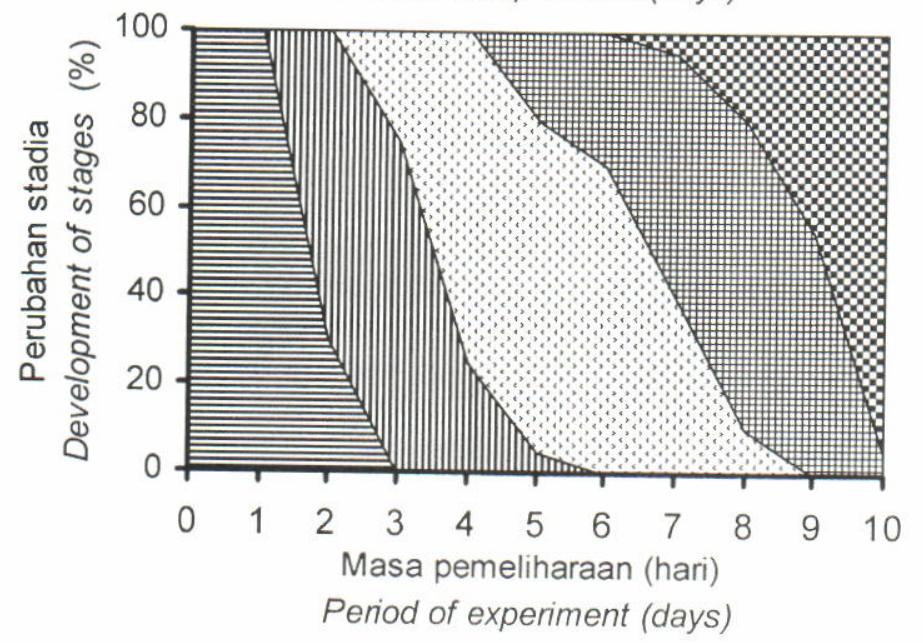

\section{$8 M$}

田Z-4

마 Z-3

띠 Z-2

目Z-1

Gambar 3. Perkembangan stadia larva rajungan (Portunus pelagicus) dari ketiga perlakuan. (Z: zoea; M: megalopa) Figure 3. Stage Development of blue swimming crab larvae from the three treatments (Z: zoea; M: megalopa) 
Penggunaan bakteri Bacillus K-7 pada pemeliharaan larva rajungan belum pernah diujicobakan, tetapi telah diaplikasikan dalam pemeliharaan larva udang dan kepiting bakau yang dilaporkan dapat menekan perkembangan bakteri (Vibrio spp.) serta meningkatkan sintasan. Rusdi et al. (2002) menjelaskan bahwa bakteri Bacillus K-7 mempunyai kemampuan yang lebih baik dalam menekan perkembangan Vibrio spp. dalam media pemeliharaan dibanding dengan probiotik produk komersial. Probiotik diproduksi dari bakteri gram negatif dan gram positif non patogen (Gil \& Raque, 1998 dalam Kamiso, 2004; Austine, 2004), dan contoh probiotik telah banyak dilaporkan seperti Lactobacillus plantarum, Lactobacillus spp., Pseudomonas sp., Bacillus spp. (Rengpipat et al., 1998). Penggunaan bakteri Bacillus K-7 (B) dalam media kultur dapat dihasilkan sintasan megalopa yang lebih baik yaitu sebesar $9,82 \%$ dibandingkan perlakuan $\mathrm{A}(8,37 \%)$ dan C $(7,90 \%)$ (Gambar 4).

Persentase sintasan yang dihasilkan dengan penggunaan probiotik dinilai masih rendah. Hal ini diduga penggunaan jenis probiotik tersebut belum dapat dimanfaatkan secara optimal oleh larva rajungan sehingga larva masih banyak yang mati.

Perkembangan populasi Vibrio spp. (Tabel 2) juga merupakan faktor penyebab tingginya mortalitas larva, terutama saat pergantian kulit (moulting) dari stadia zoea ke stadia megalopa. Moruga et al. (1989) berpendapat bahwa mortalitas massal pada larva kepiting seringkali disebabkan oleh serangan bakteri vibrio (vibriosis). Larva yang baru berganti kulit dalam kondisi lemah dan mudah terinfeksi bakteri sehingga banyak terjadi kematian. Dengan bertambahnya masa pemeliharaan yang diikuti dengan bertambahnya bakteri probiotik yang diberikan, maka akan meningkatkan daya kompetisi terhadap bakieri patogen yang akhirnya dapat meningkatkan ketahanan larva dari serangan bakter. Pengamatan populasi bakteri dalam media pemeliharaan selama percobaan dari ketiga perlakuan tersaji pada Tabel 2

Dengan pemberian bakteri probiotik, di samping dapat menekan populasi bakteri Vibrio sp., juga diketahui dapat meningkatkan keragaan megalopa dalam pembenihan rajungan. Tabel 2 memperlihatkan total populasi bakteri pada perlakuan A dan B lebih rendah dibandingkan perlakuan $\mathrm{C}\left(1,0 \times 10^{3} \mathrm{cfu} / \mathrm{mL}\right)$ sementara perlakuan $\mathrm{A}$ lebih baik dalam menekan populasi Vibrio harveyi $(0 \mathrm{cfu} / \mathrm{mL})$ dibandingkan perlakuan B $\left(2 \times 10^{2} \mathrm{cfu} / \mathrm{mL}\right)$. Garriques \& Arevalo (1995) dalam Haryanti et al. (1999) menyatakan bahwa bakteri probiotik berperan sebagai pengontrol biologis dalam akuakultur, salah satu di antaranya adalah dapat berperan dalam melakukan kompetisi dengan bakteri patogen.

Dengan pemberian probiotik diduga dapat meningkatkan vitalitas megalopa. Vitalitas tersebut dapat dilihat dari gerakan megalopa yang aktif dan dapat bertahan hidup dari beberapa jenis uji seperti uji dengan kertas tissu kering, larutan formalin, dan stresing salinitas (Tabel 3).

Dari Tabel 3 terlihat bahwa presentase kemampuan megalopa untuk bertahan hidup dan bergerak aktif dengan uji kertas kering pada perlakuan B selalu lebih baik dibandingkan perlakuan $A$ dan $C$, sementara uji formalin $100 \mathrm{mg} / \mathrm{L}$ untuk perlakuan yang menggunakan probiotik (A) dan (B) memperlihatkan vitalitas megalopa yang sama dan yang tidak menggunakan probiotik (C) menunjukkan nilai persentase

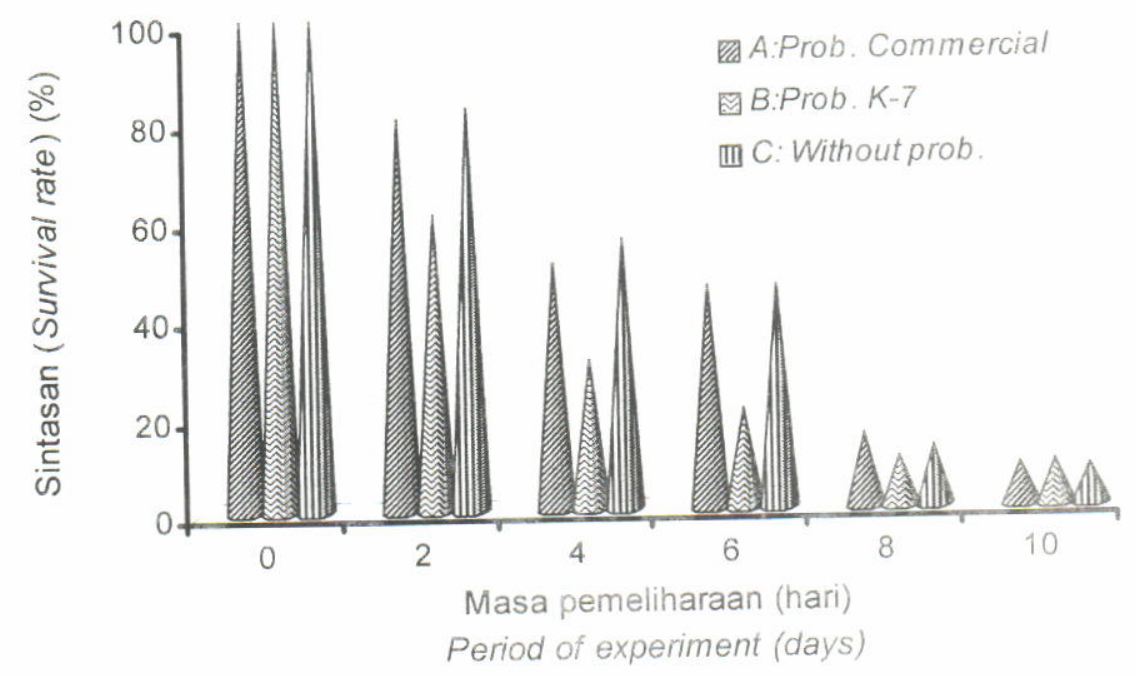

Gambar 4. Sintasan megalopa dari ketiga perlakuan

Figure 4. Survival rate of megalopa from tree treatment 
Tabel 2. Total populasi bakteri (cfu/mL) Vibrio sp. dan Vibrio harveyi pada setiap stadia pemeliharaan benih rajungan

Table 2. Population (cfu/ $\mathrm{mL}$ ) of Vibrio sp. and Vibrio harveyi on every rearing stage of blue swimming crab fry

\begin{tabular}{|c|c|c|c|c|c|c|}
\hline \multirow{2}{*}{\multicolumn{2}{|c|}{$\begin{array}{l}\text { Perlakuan } \\
\text { (Treatment) }\end{array}$}} & \multicolumn{5}{|c|}{ Stadia (Stage) } \\
\hline & & $z-1$ & $Z-2$ & $Z-3$ & $Z-4$ & $\mathbf{M}$ \\
\hline A & $\begin{array}{l}T \\
Y \\
G \\
\end{array}$ & $\begin{array}{l}9 \times 10^{2} \\
7 \times 10^{2} \\
2 \times 10^{2} \\
\end{array}$ & $\begin{array}{l}6 \times 10^{2} \\
5 \times 10^{2} \\
1 \times 10^{2} \\
\end{array}$ & $\begin{array}{c}1 \times 10^{2} \\
1 \times 10^{2} \\
0 \\
\end{array}$ & $\begin{array}{c}1.1 \times 10^{3} \\
1.1 \times 10^{3} \\
0\end{array}$ & $\begin{array}{c}9 \times 10^{2} \\
9 \times 10^{2} \\
0 \\
\end{array}$ \\
\hline B & $\begin{array}{l}T \\
Y \\
G \\
\end{array}$ & $\begin{array}{c}2 \times 10^{2} \\
2 \times 10^{2} \\
0\end{array}$ & $\begin{array}{c}7 \times 10^{2} \\
7 \times 10^{2} \\
0\end{array}$ & $\begin{array}{c}9 \times 10^{2} \\
9 \times 10^{2} \\
0\end{array}$ & $\begin{array}{l}7 \times 10^{2} \\
4 \times 10^{2} \\
3 \times 10^{2} \\
\end{array}$ & $\begin{array}{l}6 \times 10^{2} \\
4 \times 10^{2} \\
2 \times 10^{2} \\
\end{array}$ \\
\hline$C$ & $\begin{array}{l}T \\
Y \\
G\end{array}$ & $\begin{array}{c}2.4 \times 10^{3} \\
1.8 \times 10^{3} \\
6 \times 10^{2}\end{array}$ & $\begin{array}{c}2 \times 10^{2} \\
2 \times 10^{2} \\
0\end{array}$ & $\begin{array}{c}1.1 \times 10^{3} \\
1.1 \times 10^{3} \\
0\end{array}$ & $\begin{array}{c}5 \times 10^{2} \\
5 \times 10^{2} \\
0\end{array}$ & $\begin{array}{c}1.0 \times 10^{3} \\
7 \times 10^{2} \\
3 \times 10^{2}\end{array}$ \\
\hline
\end{tabular}

Keterangan (Remark): A: Commercial probiotic; B: Bacillus K-7; C: Control; Z: zoea; M: megalopa; T: Total bactery; $Y$ : Vibrio sp.; G: Vibrio harveyi

Tabel 3. Data vitalitas megalopa dari ketiga perlakuan

Table 3. Vitality of megalopa from tree treatment

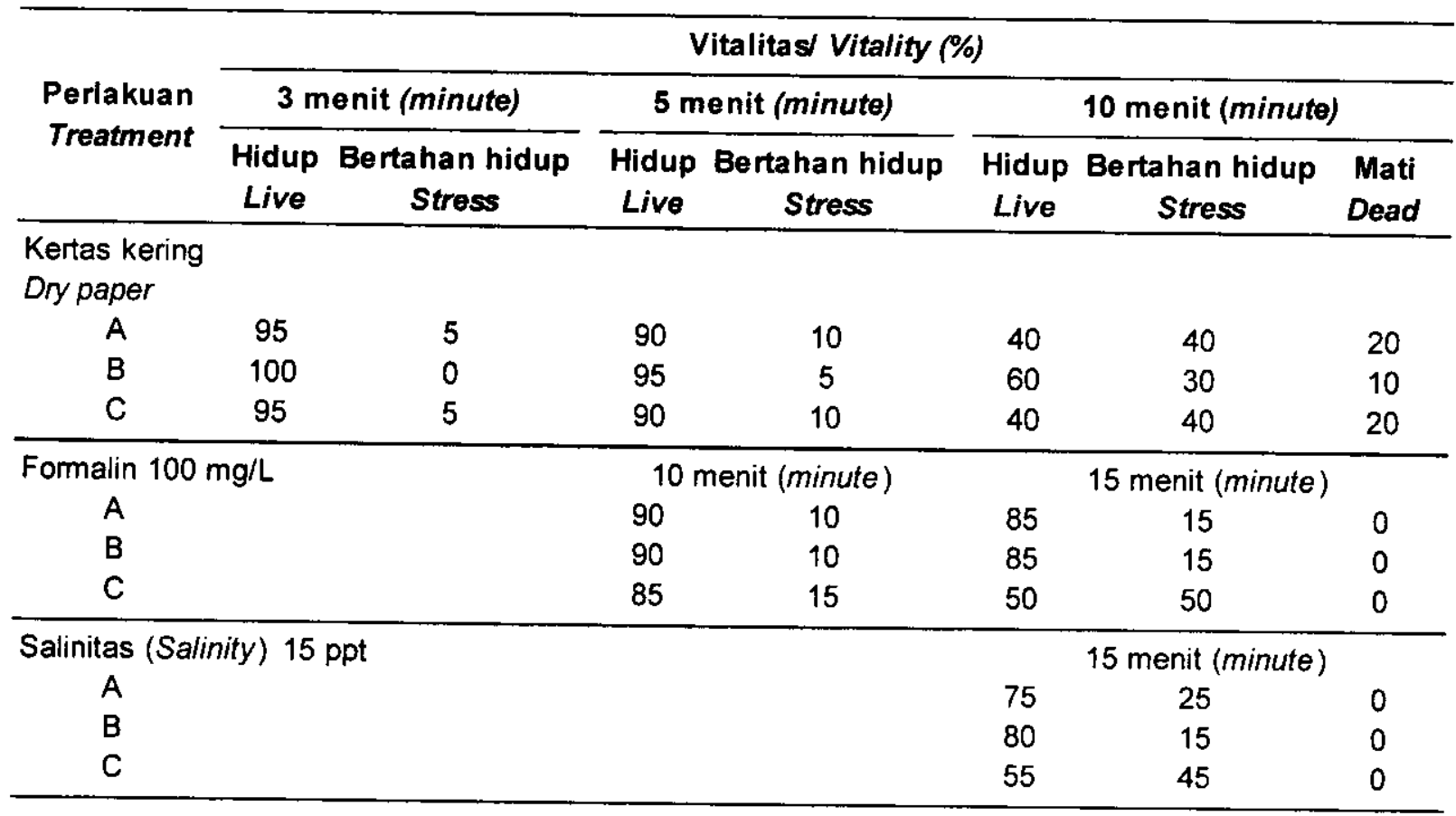

Keterangan (Remark): A: Commercial probiotic; B: Bacillus K-7; C: Control

kemampuan bertahan hidup dan bergerak aktif yang lebih rendah. Hal ini menunjukkan bahwa penggunaan probiotik akan berperan dalam meningkatkan vitalitas karena sesuai yang dilaporkan Garriques \& Arevalo (1995) dalam Haryanti et al. (1999) bahwa probiotik juga merupakan nutrea esensial dan meningkatkan daya cerna dengan mengeluarkan enzim esensial dari bakteri tersebut. Dalam uji salinitas $15 \mathrm{ppt}$, pada perlakuan $C$ terlihat megalopa memiliki persentase kemampuan yang lebih rendah untuk beradaptasi pada salinitas 15 ppt dibandingkan perlakuan yang menggunakan probiotik (perlakuan A dan B).

Hasil pengamatan kualitas air selama percobaan adalah suhu air $29,5^{\circ} \mathrm{C}-31^{\circ} \mathrm{C}$; salinitas $30-31 \mathrm{ppt}$ $\mathrm{pH} 8,1-8,3$; oksigen terlarut $5,5-5,8 \mathrm{mg} / \mathrm{L}$. Parameter kualitas air tersebut masih layak dan dapat 
digunakan untuk pemeliharaan larva rajungan. Intensitas cahaya yang dimonitor selama penelitian berkisar antara 145-186,5 lux. Juwana (2002) menyatakan bahwa suhu optimal untuk pemeliharaan zoea sekitar $30^{\circ} \mathrm{C}$ atau berkisar $27^{\circ} \mathrm{C}$ sampai $32^{\circ} \mathrm{C}$, sementara untuk stadia megalopa sekitar $34^{\circ} \mathrm{C}$. Salinitas optimum untuk zoea sekitar $27-30 \mathrm{ppt}$.

\section{KESIMPULAN}

Penggunaan probiotik dapat diaplikasikan dalam perbenihan rajungan. Probiotik Bacillus K-7 dapat memberikan keragaan pertumbuhan yang lebih baik dan stadia megalopa dapat dicapai lebih cepat. Sementara penggunaan probiotik baik komersial atau Bacillus K-7 dapat mengontrol lingkungan secara biologis dan menekan populasi bakteri serta memberikan vitalitas megalopa yang baik.

\section{DAFTAR PUSTAKA}

Austine, B. 2004. Control of fish diseases. Prosiding pengendalian penyakit ikan dan udang berbasis imunisasi dan biosecurity. Seminar Nasional Penyakit Ikan dan Udang IV, Purwokerto, 18-19 Mei 2004, 8 pp.

Brick, R.W. 1974. Effect of water quality, antibiotic, phytoplankton, and food on survival and development of larvae of Scylla serrata (Crustacea: Portunidae). Aquaculture, 3: 231-244.

Effendi, M.I. 1979. Biologi Perikanan. Yayasan Pustaka Nusantara. Yogyakarta, $163 \mathrm{pp}$.

Fuller, R. 1987. A review: probiotic in man and animal. Journal of Applied Bacteriology, 66: 365-378.

Gomes, L.A. 1992. Zen and the art of aquaforming, a close look at Thaiwanese Aquaculture practices. Word Aquaculture, 23 (3): 18-26.

Heasman, M.P. and D.R. Fielder. 1983. Laboratory spawning and mass rearing of the mangrove crab. Scylla serrata F. from first zoea to first crab stage. Aquaculture, 34: 303-316.

Haryanti, S. Lante dan S. Tsumura. 1997. Studi pendahuluan penggunaan bakteri Flavimonas BY-9 sebagai probiotik dalam pemeliharaan larva udang windu Penaeus monodon. J. Pen. Per. Indonesia, 3(1): 44-52.

Haryanti, K. Sugama, dan S. Tsumura. 1999. Penggunaan strain bakteri BY-9 dan Rhodopseudomonas 2-4 pada pemeliharaan larva udang windu Penaeus monodon. Prosiding Seminar Nasional Penelitian dan Diseminasi Teknologi Budidaya Laut dan Pantai, Jakarta 2 Desember 1999, p. $157-162$.

Haryanti, G.N. Permana, S.B. Moria, N.A. Giri, dan K. Sugama. 2002. Penggunaan bakteri probiotik Alteromonas sp. BY-9 dalam pemeliharaan larva udang melalui pakan alami dan buatan. J. Pen. Per. Indonesia, 8(5): 55-66.

Juwana, S. 2002. Crab culture technique at RDCO-LIPI, Jakarta, Indonesia 1994 to 2001. Proceedings
Workshop on Mariculture in Indonesia. Mataram, Lombok Island. Research Center for OceanographyLIPI, Institute of Marine Research Norwegian BergenNorway, $144 \mathrm{pp}$.

Kasry, A. 1986. Pengaruh antibiotik dan makanan terhadap kelulushidupan dan perkembangan larva kepiting, Scylla serrata (Forskal). J. Pen. Per. Laut, 37: $11-22$.

Kamiso, H.N. 2004. Status penyakit ikan dan pengendaliannya di Indonesia. Prosiding pengendalian penyakit ikan dan udang berbasis imunisasi dan biosecurity. Seminar Nasional Penyakit ikan dan udang IV, Purwokerto, 18-19 Mei 2004, $26 \mathrm{pp}$.

Maeda, M. 1989. Some aspect of the biocontrolling method in aquaculture. Jap. Soc. Mar. Biotechnol, p. $395-397$

Maeda, M., K. Nogami, and N. Ishibashi. 1992. Utility of microbial food assemblages for culturing a crab Portunus trituberculatus. Bull. Natl. res. Inst. Aquaculture, 21: 31-38.

Maeda, M. and I.C. Liao. 1994. Microbial processes in aquaculture environment and their importance for increasing crustacean production. JARQ, 28 (4): 283-288.

Maeda, M. 1999. Microbial Processes in Aquaculture Society for the Biological and Enhancement of the Aquatic Environment (Biocreate). United Kingdom Japan, $102 \mathrm{pp}$.

Moruga, K., K. Suzuki, N. Ishibashi, and K. Nogami. 1989. A Vibriosis in zoeal larvae of swimming crab Portunus trituberculatus. Suisanzoshoku H.1., p. 133-141.

Nogami, K. and M. Maeda. 1992. Bacterial as biocontrol agents for rearing larvae of the mud crab Portunus trituberculatus. Can. J. Fish. Aqua. Sci., 49: 2,3732,376.

Nagomi, K., M. Maeda, K. Hirayama. 1995. Effect of bacteria addition rearing water for seed production of swimming crab, Portunus trituberculatus. Using Biocontrol Method, $14 \mathrm{pp}$.

Rosa, D., Zafran, A. Perenrengi, dan T. Ahmad. 1993. Studi pendahuluan penyakit kunang-kunang pada larva kepiting bakau, Scylla serrata. J. Pen. Budidaya Pantai, 9(3): 119-24.

Rosa, D., dan Zafran. 1998. Pengendalian Vibrio harveyi secara biologis pada larva udang windu Penaeus monodon.:Aplikasi bakteri penghambat. J. Pen. Per. Indonesia, 4(2): 24-30.

Rosa, D. and K. Hatai. 1999. Pathogenicity of fungi isolated from the larvae of the mangrove crab. Scylla serrata, in Indonesia. Mycoscience, 40: 427-431.

Rusdi, I., Yunus, dan K. Sugama. 1999. Kajian produksi larva kepiting bakau Scylla paramamosain. Prosiding Seminar Nasional Penelitian dan Diseminasi Teknologi Budidaya Laut dan Pantai, Jakarta 2 Desember 1999, p. 163-167.

Rusdi, I., Haryanti, R. Melianawati, dan Yunus. 2002. Penerapan biokontrol dalam produksi benih kepiting bakau. Laporan Teknis BBRPBL-Gondol Bali, 9 pp. 
Rengpipat, S., S. Rukpratanporn, S. Piyatiratitivorakul, and P. Menasveta. 1998. A case study of probiotic for larvae of Penaeus monodon. Advanced in shrimp Biotechnology. Nat. Center for Genetic Engineering and Biotechnology. Bangkok, 177-182.

Susanto, B., M. Marzuqi, I. Setyadi, D. Syahidah, N. Permana, dan Haryanti. 2003. Pengaruh feeding regime (pola pemberian pakan) terhadap produksi massal rajungan Portunus sp. Laporan Teknis BBRPBL-Gondol Bali, 11 pp.
Yunus, K. Suwirya, Kasprijo, dan I. Setyadi. 1996. Pengaruh pengkayaan rotifer (Brachionus plicatilis) dengan menggunakan minyak hati ikan cod terhadap sintasan larva kepiting bakau (Scylla serrata). J. Pen. Per. Indonesia, 2(3): 38-45.

Zafran, D. Rosa, dan I. Koesharyani. 1997. Resistensi isolat Vibrio sp. dari beberapa panti benih udang windu (Penaeus monodon) terhadap obatobatan antibiotik. J. Pen. Per. Indonesia, 3(1): 1115. 
